DOI: 10.20472/IAC.2017.032.044

\title{
ATILA YILDIRIM
}

Necmettin Erbakan Üniversitesi, Ahmet Keleşoğlu Eğitim Fakültesi, Turkey

\section{THE VIEWS OF PROSPECTIVE TEACHERS REGARDING THE INCIVILITY LEVEL OF THE TEACHING STAFF}

\begin{abstract}
:
Workplace incivility is low-intensity deviant behavior with ambiguous intent to harm the target, in violation of workplace norms for mutual respect. Incivility behaviors are characteristically rude and discourteous, displaying a lack of regard for others. Incivility constitutes rude, insensitive, disrespectful, and thoughtless behavior with ambiguous intent to harm that is directed toward individuals (Pearson et al., 2000), teams, groups, and organizations. For example, talking down to others, not listening, belittling others, withholding information, paying little attention or showing little interest in others' opinions, making demeaning or derogatory remarks to someone and avoiding someone.

The purpose of this work, determining the views of teacher candidates for incivility level of teaching staff. In the study, data will collect from 300 prospective teachers. Research applications and data analysis is underway.
\end{abstract}

\section{Keywords:}

Incivility behaviors, the teaching staff, prospective teachers

JEL Classification: C83, 129, 123 


\section{INTRODUCTION}

Workplace incivility, defined as a deviation from institutional norms, is one of the lowest intensity of violence and maltreatment encountered in organizations. In some cases, it may be the first step leading to higher intensity forms of violence. The workplace incivility is described as a unique form of person-to-person maltreatment with character impudence, mutual disagreement and violation of respect (Blau \& Andersson, 2005). In recent years a growing amount of research has been conducted in the area of workplace incivility (Andersson \& Pearson, 1999; Cortina, Magley, Williams, \& Langhout, 2001; Pearson, Andersson, \& Porath, 2005; Penney \& Spector, 2005; Torkelson, Holm, Backstrom \& Schad, 2016). Andersson and Pearson (1999) introduced a new pattern, workplace inci-vility, refers to relatively mild, rude, and discourteous behavior in the workplace. Specifically, workplace incivility is defined as 'low- intensity deviant behavior with ambiguous intent to harm the target, in violation of workplace norms for mutual respect (Andersson \& Pearson, 1999; p. 457).' Incivility behaviors are characteristically rude and discourteous, displaying a lack of regard for others. Incivility constitutes rude, insensitive, disrespectful, and thoughtless behavior with ambiguous intent to harm that is directed toward individuals (Pearson et al., 2000), teams, groups, and organizations. For example, talking down to others, not listening, belittling others, withholding information, paying little attention or showing little interest in others' opinions, making demeaning or derogatory remarks to someone and avoiding someone. Workplace rudeness is not coming-off once or rarely, refers to the continuity of the situations.

This phenomenon, that causes many negative results in terms of employees and institutions, causes psychological and physical disturbances on the individuals, indirectly decreases the performance of the employees and willingness to work, indirectly affects the performance of the institution, damages institutional loyalty and increases the worker turnover. In general terms, this situation disrupts the organizational climate, leading to the emergence of unhealthy institutions (Güngör Delen, 2010).

Kindness may be good fort he heart. Biological chemist Davit R. Hamilton, Phd, author of "The Five Side Effects of Kindness", explains that the emotional warmth associated whit kindnessmay lead to a release of oxytocin -the so- called "love hormone." That, in turn, reduces levels of tree radicals and inflammation, two "culprits" as he calls them, thar may play a role in heart disease. Even a small act of kindness may help decrease the effects of stress. Looking out to for others, sometimes putting their needs or comfort before our own is a nice and decent way to move through the World ( Levitt, 2017). Here's a look at some recent research on why it may also be good for your health to be kind (Levitt, 2017): Scientific evidence has proven that kindness changes the brain, impacts the heart and immune system, is an antidote to depression and even slows the ageing process. Volunteering may lower the risk of developing high blood pressure in older adults. Volunteering may help you live a longer, healthier life, if you do it for the right reasons. A café operator has set a price list according to tea order shape 
from some customers. It determines the price of tea according to the polite. Tea price list: Give tea 1.75 TL, Send tea 1.50 TL, Give me tea 1.25 TL, Can I have tea $1.00 \mathrm{TL}$, Would you give me tea $0.75 \mathrm{TL}$ and if you are available can I have a tea 0.50 TL. (Milliyet, 2016).

Some suggestions (Crampton and Hodge, 2008) that can be applied to prevent disrespectful behavior in institutions: 1) Should deal with the problem, not the person, 2) Look for good aspects of the person you block or overheat, 3) Do not allow negative people to disturb you, 4) Put yourself in the shoes of the opposite person, 5) Be as positive as possible.

\section{METHODS}

This research has been carried out in accordance with the general screening model. The study was conducted in survey model and descriptive statistics.

2.1. Study model and participants

The universe of this research is composed of students of Necmettin Erbakan University Ahmet Kelesoglu Faculty of Education and the sampling of the research is made of 284 female, 105 male, in total 389 students who are studying various main disciplines of the faculty. The sampling of the survey is selected by random cluster sampling method among the students who attend faculty in the education years of 2015-2016. The students' psychological counseling and guidance department consists of 306 people, 36 pre-school, 39 special education and 8 computer teachers.

\subsection{Instruments}

School Incivility Scale (SIS), which will measure the prevalence of incivil behaviours at schools was developed by Yildirim, Unal and Surucu (2013), was used in the study. The scale was itemized according to 5 Likert Type and included 19 items. Items loaded to each factor were examined in terms of content and the factors were named trivialization, ignoring and privacy invasion. Calculated based on item analysis for the reliability of the scale, Cronbach Alpha inner consistency coefficient was .94 for trivialization dimension, .88 for ignoring dimension and .87 for Privacy Invasion dimension. 


\section{RESULTS AND FINDINGS}

Table 1. Descriptive analysis by gender

\begin{tabular}{lll}
\hline Gender & Mean N & Std. Deviation \\
\hline Female & $29,44 \quad 284$ & 10,24 \\
Male & 31,08105 & 9,70 \\
Total & 29,88389 & 10,11 \\
\hline
\end{tabular}

Male students indicated that faculty members were more disrespectful than female students.

Table 2. Analysis of incivility dimensions according to gender

\begin{tabular}{|c|c|c|c|c|}
\hline & Gender & Trivializati & oring & $\begin{array}{l}\text { Privacy } \\
\text { invasion }\end{array}$ \\
\hline & Mean & 17,18 & 8,85 & 4,69 \\
\hline Femal & $\mathbf{N}$ & 284 & 284 & 284 \\
\hline & $\begin{array}{l}\text { Std. } \\
\text { Deviation }\end{array}$ & 7,22 & 3,44 & 1,90 \\
\hline & Mean & 17,76 & 9,67 & 5,00 \\
\hline Male & $\mathbf{N}$ & 105 & 105 & 105 \\
\hline & $\begin{array}{l}\text { Std. } \\
\text { Deviation }\end{array}$ & 6,54 & 3,26 & 2,14 \\
\hline Total & Mean & 17,34 & 9,07 & 4,77 \\
\hline & $\mathbf{N}$ & 389 & 389 & 389 \\
\hline & $\begin{array}{l}\text { Std. } \\
\text { Deviation }\end{array}$ & 7,04 & 3,41 & 1,97 \\
\hline
\end{tabular}

Both female students and male students have the highest level of views on the trivialization dimension of the teaching staff's. 
Table 3. ANOVA analysis according to departments

\begin{tabular}{|c|c|c|c|c|c|c|}
\hline & & $\begin{array}{l}\text { Sum } \\
\text { Squares }\end{array}$ & of $d f$ & Mean & $\mathbf{F}$ & Sig. \\
\hline \multirow[t]{3}{*}{ Trivialization } & $\begin{array}{l}\text { Between } \\
\text { Groups }\end{array}$ & 350,311 & 3 & 116,770 & 2,384 & ,069 \\
\hline & Within Groups & s 18856,574 & 385 & 48,978 & & \\
\hline & Total & 19206,884 & 388 & & & \\
\hline \multirow[t]{3}{*}{ Ignoring } & $\begin{array}{l}\text { Between } \\
\text { Groups }\end{array}$ & 86,278 & 3 & 28,759 & 2,507 & ,059 \\
\hline & Within Groups & s 4415,984 & 385 & 11,470 & & \\
\hline & Total & 4502,262 & 388 & & & \\
\hline \multirow[t]{3}{*}{$\begin{array}{l}\text { Privacy } \\
\text { invasion }\end{array}$} & $\begin{array}{l}\text { Between } \\
\text { Groups }\end{array}$ & 4,985 & 3 & 1,662 & ,427 & ,734 \\
\hline & Within Groups & s 1497,653 & 385 & 3,890 & & \\
\hline & Total & 1502,638 & 388 & & & \\
\hline
\end{tabular}

No significant difference was found according to the students' deparment.

\section{CONCLUSION}

1. It has been observed that the rudeness (incivility) of teaching members does not make a difference according to the gender of the students.

2. According to the students' departments, it has been determined that the rudeness behaviors of the lecturers are not different.

\section{RECOMMENDATIONS}

Teaching members should be trained in gentle behavior, behavior management and adult education before and during the service, and seminars or conferences should be organized in this regard. The results of the research should be compared with similar results of the qualitative studies. It would be appropriate to conduct similar studies at pre-primary, primary and secondary levels 


\section{REFERENCES}

Andersson, L. M. \& Pearson, C. M. (1999). Tit for tat? The spiraling effect of incivility in the workplace. Academy of Management Review, 24, 452-471. doi:10.2307/259136.

Blau, G. \& Andersson, L. (2005). Testing a measure of instigated workplace incivility. Journal of Occupational and Organizational Psychology.78, 595-614.

Crampton, S. M., \& Hodge, J. W. (2008). Rudeness and incivility in the workplace. Journal of Leadership Accountability and Ethics, 8, 41-48.

Cortina, L. M., Magley, V. J., Williams, J. H. \& Langhout, R. D. (2001). Incivility in the workplace: Incident and impact. Journal of Occupational Health Psychology, 6, 64-80. doi: 10.1037//10768998.6.1.64.

Güngör Delen, M. (2010). Çalışma hayatında işyeri kabalığı olgusu. İstanbul Üniversitesi İktisat Fakültesi Maliye Araştırma Merkezi Konferansları 53. Seri.

Lim, S., Cortina, L. M. \& Magley, V. J. (2008). Personal and workgroup incivility: Impact on work and health outcomes. Journal of Applied Psychology, 93, 95-107. doi:10.1037/0021-9010.93.1.95.

Milliyet Newspaper (2016). The price of tea according to the polite, Milliyet orta anadolu eki (08 Aprl. 2016).

Penney, L.M. \& Spector, P.E. (2005). Job stress, incivility, and counterproductive work behavior (CWB): the moderating role of negative affectivity. Journal of Organizational Behavior. 26, 777-796.

Porath, C. L. \& Pearson, C. M. (2010). The cost of bad behavior. Organizational Dynamics, 39, 64-71. doi:10.1016/j.orgdyn.2009.10.006.

Reio, T.G., \& Reio, S.M. (2011). Workplace incivility in Schools. International Journal of Adult Vocational Education and Technology, 2 (1), 23-35. doi: 10.4018/javet.2011010103.

Levitt, S. (2017). The health benefits of being kind. https://www.getold.com/the-health-benefits-of-beingkind.

Smith, P., Phillips, T. L., \& King, R. D. (2010). Incivility: The rude stranger in everyday life. New York, NY: Cambridge University Press.

Torkelson, E., Holm, K., Backstrom, M. \& Schad, E. (2016) Factors contributing to the perpetration of workplace incivility: the importance of organizational aspects and experiencing incivility from others, Work \& Stress, 30:2, 115-131, DOI: 10.1080/02678373.2016.1175524

Yildirim, A., Unal, A. \& Surucu, A. (2013). Incivil behaviours at school: scale development. International Journal of Academic Research, 5(3), 152-156. doi: 10.7813/2075-4124.2013. 